\title{
KONSEP DEMOKRASI NURCHOLISH MADJID DAN IMPLEMENTASINYA DALAM FILSAFAT PENDIDIKAN ISLAM
}

\author{
Oleh. \\ Yu'timaalahuyatazaka \\ UIN Sunan Kalijaga Yogyakarta \\ yutimaalahuyatazaka@yahoo.com
}

\begin{abstract}
Democracy in Indonesia is being tested. There are several the serious issues which is highlighted recently such as money politic, political ethics, corrupt, and one of the cases of blasphemy. These problems need to be finished withthe education activities to overcome the nation's problems closely related to the issue of democracy. With the Nurcholish's concept of democracy, it is hoped to give an awareness that the democracy is the concept of Islam on the Qoran and Sunnah. Besides Islamic education can offer a new theoretical construction of democracy that can provide alternative solutions to the problems of contemporary society in Indonesia. This research uses a library research. The data is obtained by using a literature review. Then, it is understood and analyzed theoritically and philosophically. The result ofresearch is the democratic Islamic education in the idea's Nurcholish Madjid is Islamic education which prioritizes the principle of togetherness, change and development. Islamic education also needs to instill Indonesian-ness and modernity values in addition to Islam itself.
\end{abstract}

Keywords : Islamic Education, Democracy, Nurcholish Madjid

\begin{abstract}
Abstrak
Demokrasi di Indonesia sedang diuji. Ada beberapa masalah serius yang disorot baru-baru ini seperti politik uang, etika politik, korupsi, dan salah satu kasus penistaan agama. Masalah-masalah ini perlu diselesaikan dengan kegiatan pendidikan untuk mengatasi masalah bangsa terkait erat dengan masalah demokrasi. Dengan konsep demokrasi Nurcholish, diharapkan memberikan kesadaran bahwa demokrasi adalah konsep Islam tentang Alquran dan Sunnah. Selain itu pendidikan Islam dapat menawarkan konstruksi teoretis baru demokrasi yang dapat memberikan solusi alternatif untuk masalah masyarakat kontemporer di Indonesia. Penelitian ini menggunakan penelitian kepustakaan. Data diperoleh dengan menggunakan tinjauan pustaka. Kemudian, dipahami dan dianalisis secara teoretis dan filosofis. Hasil penelitian adalah pendidikan Islam yang demokratis dalam gagasan Nurcholish Madjid adalah pendidikan Islam yang mengedepankan prinsip kebersamaan, perubahan, dan pembangunan. Pendidikan Islam juga perlu menanamkan nilai-nilai keindonesiaan dan modernitas di samping Islam itu sendiri.
\end{abstract}

Kata kunci: Pendidikan Islam, Demokrasi, Nurcholis Madjid 


\section{A. PENDahuluan}

Terdapat relasi resiprokal antara dunia pendidikan dengan kondisi sosial masyarakat. Relasi ini bermakna bahwa apa yang berlangsung dalam dunia pendidikan merupakan gambaran dari kondisi yang sesungguhnya dalam kehidupan masyarakat yang kompleks. ${ }^{1}$ Salah satu persoalan yang kini menjadi tantangan besar, termasuk bagi dunia pendidikan adalah proses demokrasi di Indonesia. Sehingga, semua proses yang menyangkut persoalan tersebut membutuhkan kontribusi pendidikan untuk menyelesaikannya.

Pendidikan merupakan landasan utama serta mendasar dalam mewujudkan sebuah perubahan. Hanya dengan pendidikanlah paradigma, sikap dan perilaku umat manusia dapat berubah dan tercerahkan. Dengan demikian, sangat benar adanya menurut Jhon Locke, menggemakan pentingnya pendidikan. Menurut Locke, "sejaklahir manusia merupakan sesuatu yang kosong dan dapat diisi dengan pengalaman-pengalaman yang diberikan lewat pendidikan dan pembentukan yang terus menerus. ${ }^{2}$

Penyelenggaraan demokrasi di Indonesia sedang diuji, begitulah kiranya yang menjadi bahan perhatian kita sebagai warga negara Indonesia. Persoalan yang menimpa bangsa erat kaitannya dengan proses penyelenggaraan demokrasi. Ada

\footnotetext{
1 Ngainun Na'im dan Achmad Sauqi, Pendidikan Multikultural: Konsep dan Aplikasi (Yogyakarta: Ar-Ruzz Media, 2010), hlm. 13.

2 Umiarso dan Zamroni, Pendidikan Pembebasan dalam Perspektf Barat dan Timur (Yogyakarta; Ar-Ruzz Media, 2011), hlm 7
}

beberapa persoalan serius yang disoroti akhir-akhir ini seperti praktikpolitik uang, persoalan etika politik, KKN, dan persoalan sosial-keagamaan yang semakin kompleks.Persoalan demikian merupakan batu ujian bagi bangsa kita dalam proses membangun sistem demokrasi di Indonesia.

Persoalan di atasapabila tidak segera diselesaikan, maka dapat mencederai demokrasi dan kebhinekaan yang telah terajut di bumi pertiwi ini.Ada kalangan yang menilai apabila hukum tunduk pada tekanan masa mayoritas, maka pemerintah dan aparat dinilai membuka ruang bagi praktik anti-demokrasi di Indonesia.Praktik demikian terjadi karena adanya ketidakadilan dan bahkan adanya tekanan-tekanan terhadap kelompok tertentu, sehingga menuntut pemerintah untuk memenuhi hak-hak mereka.Sebagai contoh, ialah persoalan politik yang baru saja terjadi, sehingga menumbuhkan gerakan kelompok besar umat Islam yang menyebut dengan gerakan aksi 212.Gerakan demikian muncul karena ada sebagian kelompok yang merasa hak-hak mereka belum dipenuhi, merasa adanya ketidakadilan, dan munculnya pandangan negatif dari kelompok tertentu kepada kelompok lain. Oleh karenanya, diperlukan keadilan hukum untuk menuntaskan persoalan yang kian hari kian meruncing.

Persoalan politik identitas di Indonesia semakin menguat, hal ini dibuktikan dengan survey LIPI yang menyimpulkan bahwa intoleransi 
politik tinggi dikarenakan faktor agama. Misalnya, menolak orang yang berbeda pandangan politik, dan juga berusaha mencegah pemilih lain berbeda pendapat, tingginya fanatisme keagamaan, ada sebagian kelompok yang setuju penerapan peraturan syariah. Dalam catatan, ada 57,58\% responden menyatakan hanya akan memilih pemimpin yang seagama, dari level RT sampai Presiden. ${ }^{3}$

Hal ini menunjukkan bahwa, politik di Indonesia tidak lepas dari baju agama.Agama dijadikan sebagai alat politik untuk meraih kekuasaan.Symbol-simbol agama lebih diutamakan daripada esensi beragama. Maka, symbol agama kian hari menjadi semakin sakral karena dianggap sama seperti agama itu sendiri.Kasus yang terjadi akhir-akhir ini, ialah pembakaran bedera tauhid oleh oknum tertentu sehingga menimbulkan reaksi keras dan masa yang protes turun ke jalan juga semakin meluas.Banyak yang dituduh telah menghina/melecehkan agama tertentu, sehingga timbulah pelaporan-pelaporan atas dugaan pelecahan agama.Belum lagi, ada sebagian kelompok yang merasa bahwa ada kelompok agama lain yang mendominasi ruang publik.

Dari gambaran di atas, dapat disimpulkan bahwa gejala konservatisme dan fundamentalisme beragama semakin menguat di Indonesia. Paham keagamaan yang rigid, taken for granted, tekstual, lebih mengutamakn truth claim atau

3 Tempo, "LIPI: Intoleransi Politik Tinggi karena Faktor Agama", diakses pada 7 desember 2018 eksklusivisme beragama lebih diminati oleh sebagian kalangan masyarakat.Agama tidak bisa dipisahkan dari politik merupakan keyakinan yang mengakar kuat dalam diri sebagian masyarakat Muslim di Indonesia.Penafsiran dan pemahaman tunggal agama kian hari kian absolut, dan menjadi setara dengan agama itu sendiri.Maka, kemungkinan untuk toleransi terhadap perbedaan tafsir dan pemahaman keagamaan semakin sulit terwujud.Dengan demikian, ruangruang untuk bersikap keras terhadap orang yang berbeda tafsir, keyakinan, pandangan politik dan ideologi semakin menguat.Dan bahkan, akhirakhir ini sering terjadi persekusi terhadap orang tertentu yang dianggap menghina tokoh, pelecehan terhadap agama, dan bahkan hanya perbedaan politik.

Perbedaan dan keanekaragaman di dalam masyarakat yang menganut sistem demokrasi tentunya dianggap sebagai yang sudah sewajarnya terjadi.Pada tingkat elit tertentu, mereka pada umumnya dapat menerima perbedaan dan keanekaragaman, sehingga dapat merajut tenun kebangsaan. Lain halnya di masyarakat kita (kalangan grassroots), kadang perbedaan dan keanekaragaman kurang diberi ruang toleransi sehingga dapat mengakibatkan chaos dan konflik di dalamnya. Dalam beberapa tahun terakhir masih terjadi gejala terorisme, radikalisme, intoleransi antarumat beragama dan penodaan atau penistaan agama. Persoalan demikian masih menunjukkan betapa sistem demokrasi 
yang dijalankan masih kurang memenuhi kriteria yang ideal.

Dalam beberapa tahun terakhir, terjadi puluhan kasus konflik dan kekerasan, seperti teror bom bunuh diri pada 15 april 2011 yang lalu dengan sasaran jama'ah jum'at masjid AdzDizkro yang ada di komplek Mapolresta Cirebon. Bom bunuh diri serupa terjadi di depan Gereja Bethel Injil Sepenuh Kepunton Solo hari minggu pada tanggal 25 desember 2011. ${ }^{4}$ Demikian pula, peristiwa Ahmadiyah harus menanggung resiko yang amat menyedihkan akibat ulah kelompok radikalisme Islam. ${ }^{5}$ Konflik Sunni-Syiah di Sampang Madura. Belum lagi, kasus umat Nasrani dari Gidi (Gereja Injili di Indonesia) menyerang umat Islam yang sedang melaksanakan shalat Idul Fitri 1 Syawal 1436 H di Markas Korem 1702-11 di Tolikara hingga berujung pada pembakaran masjid pada $17 \mathrm{Juli}$ 2015. Konflik antar umat beragama di Aceh Singkil hingga berakibat pada pembakaran gereja pada 13 Oktober 2015.

Selain itu di sepanjang tahun 2018, konflik antaragama masih terjadi secara massif, seperti kejadian di Lumajang tepatnya di Lenduro di mana ada sekelompok orang yang tak dikenal merusak tempat ibadah umat Hindu yaitu Pura.Penyerangan ulama di Lamongan, perusakan masjid di Tuban, ancaman bom di Klenteng Kwan Tee

${ }^{4}$ Bilver Singh dan Abdul Munir Mulkhan, Jejaring Radikalisme Islam di Indonesia: Jejak Sang Pengantin Bom Bunuh Diri (Yogyakarta: JogjaBangkit Publisher, 2012), hlm. 27.

${ }^{5}$ Moh Shofan, Pluralisme Menyelamatkan Agama-Agama (Yogyakarta: Samudra Biru, 2011), hlm. 37 .
Koen Karawang, serangan di Gereja Santa Lidwina di Sleman Yogyakarta, segerombolan masa bercadar yang membubarkan acara tradisi sedekah laut di Bantul Yogyakarta dan lainlain.Hal ini menunjukkan bahwa keasadaran toleransi antarumat beragama masih rendah dan perlu adanya penangan lebih lanjut baik dari pemerintah, aparat penegak hokum, tokoh masyarakat, maupun tokoh agama dalam upaya pemecahan masalah atau minimal meminimalisir terjadinya konflik antarumat beragama tersebut.

Demokrasi dalam perspektif Islam akan membentuk masyarakat madani (civil society) yang memprioritaskan kebebasan berpikir, berpendapat, beragama dan berkeyakinan, persamaan hukum, hak dan kewajiban, tegaknya hukum, keadilan dan persatuan, yang berimplikasi pada terbentuknya suatu tatanan masyarakat yang ideal (baldatun thoyyibatun wa robbun ghofur). Namun, apa yang telah dipraktikkan oleh Nabi Muhammad dan menjadi landasan normatif kini tak lagi bisa diharapkan dan kesadaran bahwa Islam benar-benar menawarkan prinsip demokrasi yang menjunjung tinggi hak-hak asasi kemanusiaan universal sudah terabaikan.

Dalam dunia pendidikan, sistem demokrasi diharapkan dapat memberikan nilai-nilai luhur bagi peserta didik.Nilai-nilai luhur tersebut diharapkan dapat tertanam dengan kuat dalam diri peserta didik, sehingga begitu mereka berkecimpung dalam masyarakat luas, mereka dapat 
mengaktualisasikan nilai-nilai luhur tersebut ke dalam suatu masyarakat untuk menciptakan tatanan sosial yang harmonis dan demokratis.

Selain itu, pendidikan perlu mengembangkan potensi peserta didik secara optimal dengancara menanamkan prinsip-prinsip demokrasi dalam proses pendidikan. Potensipotensi tersebutakan muncul seiring dengan diberikannya kebebasan kepada peserta didik dalam menampilkan siapa dirinya yang sesungguhnya. Dari sinilah pendidikan dapat berperan aktif dalam membuka pintu selebar-lebarnya untuk mewujudkan potensi-potensi peserta didikdemi kelangsungan proses demokrasi.

Pendidikan sebagai salah satu sarana untuk menumbuhkembangkan kesadaran demokrasi dapat menjadi salah satu solusi untuk mengatasi persoalan bangsa. Penanaman nilainilai kebersamaan, kemufakatan, kejujuran, etika, akhlak, moral, keadilan, dan seterusnya dapat melalui pendidikan. Oleh karenanya, diperlukan konsep yang tepat untuk menyusun konstruksi pendidikan Islam yang demokratis, agar pesan subtansial demokrasi dapat terwujud ke peserta didik. Konsep tersebut tidak lain ialah konstruksi pemikiran yang sistematis tentang demokrasi yang kemudian diimplementasikan dalam pendidikan Islam. Implementasi konstruksi pemikiran sistematis tersebut dapat diwujudkan dengan menggunakan perspektif filosofis terhadap pendidikan Islam.

Dengan demikian menarik apabila ditelaah lebih lanjut mengenai konstruksi dasar pemikiran Nurcholish Madjid tentang demokrasi khususnya yang mengarah pada terbentuknya peradaban masyarakat madani, kemudian dapat ditelaah dalam perspektif filsafat pendidikan Islam. Dengan konsep Nurcholish tentang demokrasi, diharapkan dapat memberikan kesadaran bahwa demokrasi adalah konsep yang islami. Selain pendidikan Islam dapat menawarkan konstruksi teori yang baru tentang demokrasi yang dapat memberikan solusi alternatif terhadap problematika kehidupan kontemporer masyarakat Indonesia. Dari sinilah akan terwujud konsep Pendidikan yang demokratis dalam bingkai keislaman, keindonesiaan dan kemoderenan.

\section{B. PENGERTIAN DEMOKRASI}

Demokrasi berasal dari kata "demos" yang berarti rakyat, dan "cratos" yang berarti kekuatan atau kekuasaan. Maka kata demokrasi berarti kekuasaan yang ada pada tangan rakyat. Disebut juga bahwa demokrasi adalah sistem dimana kedaulatan tertinggi ada di tangan rakyat. Dari sistem ini kemudian muncul sejumlah syarat untuk disebut sebuah negara atau satu sistem pemerintahan melaksanakan demokrasi, yakni tidak ada paksaan terhadap pengungkapan pendapat, kebebasan pers dan kebebasan berkumpul. Karena itu, asas terpenting dari sebuah demokrasi adalah adanya kebebasan berpendapat, kebebasan memilih dan semacamnya. ${ }^{6}$

\footnotetext{
${ }^{6}$ Khoiruddin nasution, Pengantar Studi Islam (Yogyakarta: Accademia, 2009), hlm. 246.
} 
Demokrasi identik dengan membentuk suatu lembaga legislatif. konsep negara modern, sehingga Hal ini dimungkinkan oleh kenyataan banyak negara mulai menerapkan suatu jumlah penduduk negara-negara kota proses demokratisasi menuju negara kurang lebih 10.000 jiwa dan bahwa demokrasi sebagaimana ungkapan wanita, anak kecil serta para budak Bryce bahwa masa depan merupakan tidak mempunyai hak politik. Tidak milik demokrasi. ${ }^{7}$ Dalam memahami ada pemisahan kekuasaan ketika itu, wacana demokrasi terdapat berbagai dan semua pejabat bertanggung jawab pernyataan intelektual baik dari Islam maupun dari Barat tetapi pernyataan tersebut tidak disertai dengan penjelasan yang mendetail secara kritis dan argumentatif sehingga mengesankan sebagai suatu premis atau asumsi yang cenderung spekulatif. Seperti Taufiq Al Syawi mengatakan demokrasi merupakan bentuk syura versi Eropa, namun tidak sama benar. ${ }^{8}$

Demokrasi adalah suatu sistem politik dan sosial yang membangun hubungan antara individu masyarakat dan negara dan keikutsertaan mereka secara bebas dalam membuat undangundang hukum yang mengatur kehidupan umum yang mengacu pada prinsip yang mengatakan bahwa rakyat adalah pemilik kekuasaan dan sumber hukum. 9 Secara historis, istilah demokrasi telah dikenal sejak abad ke5 SM, yang pada awalnya sebagai respon terhadap pengalaman buruk monarkhi dan kediktatoran di negaranegara kota Yunani kuno. Pada waktu itu demokrasi dipraktekkan sebagai sistem di mana seluruh warga negara

7 Dafid E. Apter, Pengantar Analisa Politik, terj. Tim Yogosama, (Jakarta: Rajawali, 1989), hlm 321

8 Taufiq Al-Syawy, Syura Bukan Demokrasi, terj. Jamaluddin ZS, (Jakarta: Gema Insani Pers, 1992), hlm. 21

9 Muhammad Imarah, Perang Terminologi Islam Versus Barat., (Jakarta: Rabbani Press, 1998), hlm. 178 sepenuhnya pada Majelis rakyat yang memenuhi syarat untuk mengontrol berbagai persoalan eksekutif, yudikatif dan legislatif. ${ }^{10}$

Demokrasi banyak dipakai suatu negara dengan banyak macammacamnya. Jadi, mengenai macammacam demokrasi dapat dikelompokkan dalam beberapa pembagian antara lain sebagai berikut. .

1. Demokrasi Langsung (Direct Democracy): Pengertian demokrasi langsung adalah demokrasi yang secara langsung dalam melibatkan rakyat untuk pengambilan keputusan terhadap suatu negara. Demokrasi langsung, rakyat secara langsung berpartisipasi dalam pemilihan umum dan menyampaikan kehendaknya.

\section{Demokrasi Tidak Langsung} (Indirect Democracy): Pengertian demokrasi tidak langsung adalah demokrasi yang tidak secara langsung melibatkan seluruh rakyat suatu negara dalam pengambilan keputusan. Demokrasi tidak langsung, rakyat menggunakan wakil-wakil yang telah dipercaya untuk menyampaikan aspirasi dan kehendaknya. Sehingga dalam

10 The New Encyclopedia Britannica, Vol. 4, Micropaedia, Encyclopedia Britania Inc, (Ney York: Chicago Press, 1988), hlm, 5 
demokrasi tidak langsung wakil rakyat terlibat secara langsung dengan menjadi perantara seluruh rakyat.

3. Demokrasi Formal: Pengertian demokrasi formal adalah demokrasi yang berfokus dari bidang politik tanpa mengurangi kesenjangan ekonomi

4. Demokrasi Material: Pengertian demokrasi material adalah demokrasi yang berfokus di bidang ekonomi tanpa mengurangi kesenjangan politik.

5. Demokrasi Gabungan: Pengertian demokrasi gabungan adalah demokrasi yang berfokus sama besar baik di bidang politik dan ekonomi. ${ }^{11}$

Demokrasi di bidang pendidikan merupakan suatu keharusan agar dapat melahirkan manusia-manusia yang berwatak demokratis. Reformasi pendidikan melalui demokrasi pendidikan, menurut Zamroni dapat dilakukan dalam tiga aspek pendidikan, yaitu regulatori, profesionalitas dan manajemen. Aspek regulatori dititikberatkan pada aspek reformasi kurikulum yang berkaitan dengan rumusan tujuan pendidikan, penerapan kurikulum berbasis kompetensi, pergeseran kerja guru dari responsibility ke accountability, dan pelaksanaan evaluasi dengan esai dan portofolio. Aspek profesionalitas ditujukan untuk mengembangkan hakhak dan wewenang kepada guru dalam

11 Pengertian Demokrasi, Macammacam, ciri-ciri, definisi para ahli, prinsip dan nilaihttp://www.artikelsiana.com/2015/08/dem okrasi-pengertian-ciri-ciri-macam.html melaksanakan tugas kependidikannya. Aspek ini dapat ditempuh melalui pengembangan kesadaran hak-hak politik guru untuk mengembangkan dirinya.

Adapun pendidikan demokrasi berkaitan dengan bagaimana proses pendidikan itu dilaksanakan di tingkat lokal. Di dalam pendidikan demokrasi, proses pembelajaran di kelas dapat diarahkan pada pembaruan kultur dan norma keadaban. Fungsi pendidik dalam proses pembelajaran yang demokratis adalah sebagai fasilitator, dinamisator, mediator dan motivator. Sebagai fasilitator, pendidik harus memberikan kesempatan kepada peserta didik untuk mencoba menemukan sendiri makna informasi yang diterimanya. Sebagai dinamisator, pendidik harus berusaha menciptakan iklim pembelajaran yang dialogis dan berorientasi pada proses. Sebagai mediator, pendidik harus memberikan rambu-rambu atau arahan agar peserta didik bebas belajar. Sebagai motivator, pendidik harus selalu memberikan dorongan agar peserta didiknya bersemangat dalam menuntut ilmu.

Pendidikan demokrasi menuntut adanya perubahan asas subject matter oriented menjadi student oriented. Proses pendidikan selama ini terkesan menganut asas subject matter oriented, yaitu bagaimana membebani peserta didik dengan informasi-informasi kognitif dan motorik yang kadangkadang kurang relevan dengan kebutuhan dan tingkat perkembangan psikologis mereka. Dengan orientasi seperti ini dapat dihasilkan lulusan yang pandai, cerdas dan terampil, tetapi 
kepandaian dan kecerdasan intelektual tersebut kurang diimbangi dengan kecerdasan emosional. Keadaan demikian terjadi karena kurangnya perhatian terhadap ranah afektif. Padahal ranah afektif sama pentingnya dalam membentuk perilaku peserta didik.

Suasana pendidikan yang demokratis senantiasa memperhatikan aspek egalitarian antara pendidik dan peserta didik. Pengajaran tidak harus top down, namun diimbangi dengan bottom up. Tidak ada lagi pemaksaan kehendak dari pendidik, tetapi akan terjadi tawar menawar dari kedua belah pihak dalam menentukan tujuan, materi, media, dan evaluasi hasil belajarnya. Dengan komunikasi kultural dan struktural antara pendidik dan peserta didik, akan terjadi interaksi yang sehat, wajar dan bertanggungjawab. Peserta didik boleh saja berpendapat, berperasaan, dan bertindak sesuai langkahnya sendiri, asalkan ada argumentasi yang dapat dipertanggungjawabkan secara ilmiah. Peserta didik bukan hanya memahami demokrasi, tetapi juga menjalani latihan seperti berdebat, menghargai pandangan dan harga diri orang lain, serta mematuhi aturan hukum yang diaplikasikan dalam setting diskusi. ${ }^{12}$

\section{KONSTRUKSI PEMIKIRAN NURCHOLISH MADJID TENTANG DEMOKRASI}

Demokrasi adalah suatu konsep yang sulit untuk didefinisikan.

12 Toto Suharto, Filsafat Pendidikan Islam (Yogyakarta: Ar-Ruzz, 2006), hlm. 178 183.
Demokrasi adalah sinonim dengan poliarchy. Demokrasi dalam pengertian itu bukanlah sistem pemerintahan yang mencakup keseluruhan cita-cita demokratis tetapi yang mendekatinya sampai batas-batas yang pantas. Nurcholis Madjid mengutip dari pamflet yang diterbitkan USIS, 1991 tentang "apa itu demokrasi" dikatakan, bahwa semua demokrasi adalah sistem di mana warganya bebas mengambil keputusan berdasarkan kekuasaan mayoritas. Tetapi kekuasaan oleh mayoritas tidak selalu demokratis. Bagaimana suatu sistem bisa disebut demokratis jika misalnya suara pemilu $51 \%$ penduduk menindas sisanya $49 \%$ atas nama mayoritas? kekuasaan mayoritas haruslah digandengkan dengan jaminan perlindungan hak-hak asasi manusia termasuk perlindungan atas hak-hak minoritas. Demokrasi bukanlah suatu sistem sosial politik dengan konsep yang tunggal. Hampir semua bangsa yang mempraktekannya mempunyai pandangan, pengertian dan cara-cara pelaksanaannya sendiri yang khas. Selain tuntutan kekhususan budaya yang bersangkutan, juga karena perbedaan atau kemajuan bangsa itu di bidang-bidang lain seperti ekonomi dan pendidikan. ${ }^{13}$

Dalam prakteknya, demokrasi sebagai cara dan proses menyebabkan prinsip-prinsip demokrasi sangat beragam dari satu negara ke negara lain. Negara-negara dengan sistem demokratisnya yang paling mantap dan

13 Nurkhalis, Konstruksi Demokrasi dalam Pemikiran Nurcholish Madjid dalam "Sosio-Religia Vol. 10, No.1, Februari 2012", hlm. $164-165$. 
mapan pada saat sekarang ini, berbeda dengan kesan sepintas kebanyakan orang yang kita dapati justru berbentuk kerajaan, yaitu Inggris, Belanda, Belgia, Norwegia, Swedia, Denmark dan Luxemburg, ditambah dengan Kanada, Australia dan Selandia Baru yang mengakui Mahkota Inggris Raya sebagai kepala negara masing-masing, serta beberapa negara berbentuk republik yang sangat stabil seperti Swiss, Irlandia dan Amerika Serikat. Tetapi republik-republik demokratis lainnya mengalami kegoncangan dalam tingkat tertentu, seperti Perancis, Jerman Barat dan Italia. Jepang dan India adalah negeri-negeri demokratis yang mapan setelah PD II. Jepang mempunyai segi keunikan karena sejauh ini merupakan satu-satunya negeri bukan Barat yang demokratis dan sekaligus maju industrinya. ${ }^{14}$

Setelah hampir setengah abad merdeka, berbicara demokrasi di Negeri kita ibarat mengunjungi sebuah rumah antik. Misalnya, rumah Thomas Jafferson, orang yang mengaku segan beragama tapi sepenuhnya percaya kepada Tuhan Yang Maha Esa dan nilai-nilai universal. Kita mungkin dapat memahami desain, tataruang dan susunan perabotannya, tapi belum tentu dapat dengan tepat punya gambaran bagaimana penghuninya dulu hidup. Dan "demokrasi" memang barang antik.

Demokrasi antik di Indonesia bukan ide dasarnya, melainkan kontroversinya. Dalam sejarah sekitar

14 Nurcholish Madjid, Islam, Doktrin dan Peradaban (Jakarta: Dian Rakyat, 2008) hlm. 204. proklamasi, kita dapati masalah demokrasi telah menjadi bahan perdebatan sengit antara para pendiri republik. Kita merasa kenal dengan jargon-jargon mereka "dewan", "perwakilan", "rakyat", "majelis", "musyawarah", "mufakat" dan seterusnya. Juga ada pinjaman yang lebih kontemporer: "delegation of authority", "decision by repretentation", "rule of law", "majority rule and minority right". Kita mengenal semua. Tapi rasanya tidak mungkin mengakui benar-benar mengerti maksudnya, apalagi menggambarkan dengan tepat bagaimana masing-masing yang mengklaim demokrasi itu bertingkah laku. Malah, konon ada diantara mereka yang begitu bersemangat mengumandangkan demokrasi, namun dalam hidup nyata sehari-harinya sendiri.

Tapi para "penghayat demokrasi” barangkali masih harus mempelajari pandangan teoritis yang lebih absah tentang kekuasaan politik di kalangan rakyat. Seperti menjadi sasaran kritik pedas para sarjana Syiah (Hamid Inayat, misalnya), teori politik kaum sunnah (jadi, tentunya menyangkut sebagian besar rakyat kita) sangat berat berorientasi kepada keamanan dan kestabilan, sehingga menjadi konservatif dan anti perubahan, sebab suatu perubahan dapat membawa kekacauan. Maka kiyai Sholih dari Semarang menegaskan perlunya umat Islam berpegang pada pandangan politik Sunni klasik bahwa pemberontakan kepada kekuasaan yang sah, biarpun zhalim, adalah terlarang 
menurut agama, meskipun tetap wajib melakukan amar ma'ruf nahi munkar. Atau lihat Ibn Taimiyah yang katanya, panutan kaum "modernis", dia berkata "Tuhan mendukung kekuasaan yang adil meskipun kafir, dan tidak mendukung kekuasaan yang dzalim meskipun Islam". ini karena baginya, ideatum Islam tentang kekuasaan dan negara adalah keadilan. ${ }^{15}$

Menurut Nurcholish, demokrasi memang menampakkan salah satu sisinya dalam pemilihan umum yang bebas dan pemberian suara secara rahasia. Akan tetapi, demokrasi tidak berhenti disitu. Demokrasi mesti "tinggal" di tengah masyarakat. Masyarakat itulah yang disebut masyarakat madani (civil society). Dalam masyarakat madani, terdapat berbagai perserikatan, persatuan, federasi yang bergabung untuk menjadi perisai antara negara dan warganya. Dalam kenyataannya, civil society lebih dari sekadar campuran berbagai bentuk asosiasi. Civil society membutuhkan kualitas civility, yang mana tanpanya lingkungan hidup sosial akan hanya terdiri dari faksi-faksi, dan serikat-serikat rahasia yang saling menyerang. Civility mengandung makna toleransi, kesediaan menerima berbagai pribadi, untuk menerima perbedaan, juga kesediaan untuk menerima bahwa sesuatu persoalan dapat saja tak terpecahkan. Menurut Nurcholish, meskipun masyarakat madani dapat berfungsi sebagai oposisi terhadap pemerintah, pemerintah mesti

15 Nurcholish Madjid, Pintu-pintu Menuju Tuhan (Jakarta: Dian Rakyat, 2008), hlm. $257-260$ tetap menjalankan fungsinya sebagai pemegang hukum, pembuat aturan, dan penertib masyarakat madani karena civil society bukanlah pemerintah. ${ }^{16}$

Nurcholish menawarkan tujuh Prinsip Demokrasi yang sebenarnya layak dipikirkan untuk ditarik menjadi sebuah konsep yang lebih aplikatif dan bisa dijadikan sebagai tegaknya demokratisasi di Indonesia, ketujuh prinsip tersebut sebagai berikut:

Pertama, Prinsip Kesadaran Kemajemukan. Apa yang ingin digambarkan dari prinsip yang pertama ini adalah bahwa Cak Nur melihat kemajemukan adalah seseatu yang given artinya seseuatu yang memang merupakan kodrat kemanusiaan. Perbedaan Ras, Agama dan Pendapat merupakan sesuatu yang alamiah, justru dengan kemajemukan itu manusia bisa saling mengisi dan menghargai. Sebuah fallacy (sesat pikir) jika manusia dalam pandangan Cak Nur menganggap Kemajemukan adalah satu hal yang patut dipertentangkan. Dalam konteks politik kesadaran akan kemajemukan juga merupakan satu hal penting untuk membina demokrasi yang permanen, banyangkan saja jika logika kemajemukan tidak ada maka tidak ada yang mananya political bargaining, konsesi politik dan sebagianya itu yang membuat politik penuh dengan dinamika.

16 David Edison, Konsep Nurcholish Madjid Tentang Demokrasi Indonesia, http://www.kompasiana.com/05101988/konsep -nurcholish-madjid-tentang-demokrasiindonesia_550efbb5813311c82cbc66b2 dalam Google.com diakses pada 4 April 2017 
Kedua, Prinsip Cara Haruslah Sejalan Dengan Tujuan. Dalam demokrasi yang baik Cak Nur juga menawarkan ide bahwa nilai-nilai demokrasi yang baik itu haruslah didasari dengan cara atau jalan yang baik untuk mencapainya. Jika cara yang digunakan untuk mencapai nilai demokrasi tersebut dicapai dengan jalan yang tidak baik maka nilai demokrasi yang terbangun juga akan menjadi tidak baik. Sebagai contoh adalah prilaku politik uang dalam setiap kompetisi politik, hal ini yang dilihat Cak Nur sebagai sebuah cara yang salah untuk memenangkan kompetisi politik. Dalam politik kita memerlukan uang akan tetapi yang kita perlukan adalah uang politik untuk mendukung aktivitas politik bukannya politik uang.

Ketiga, Prinsip Pemenuhan Kehidupan Ekonomi. Demokrasi politik mesti "dibarengi" dengan Demokrasi Ekonomi itulah logika ideal dari demokrasi yang sesungguhnya. Artinya bahwa pemenuhan kehidupan pokok seperti sandang, pangan dan papan harus menjadi dimensi yang terpenuhi terlebih dahulu sebelum merangkak pada membicarakan bangunan sistem demokrasi. Politik kontemporer kita misalkan dapat dijadikan contoh bagaimana kemandeg-an demokrasi tercipta akibat persoalan-persoalan domestik bangsa seperti kelaparan dan kemiskinan.

Keempat, Prinsip Kebebasan Nurani. Menurut Cak Nur prinsip ini ingin meneguhkan egalitarianisme dan kesantunan politik, pada intinya bahwa demokrasi menolak masyarakat yang terkotak-kota dan saling mencurigai satu dengan yang lainnya. Sehingga untuk meredam hal tersebut perlunya kebebasan nurani tidak terinterupsi

$$
\text { Kelima, Prinsip Musyawarah. }
$$

Menurut Cak Nur prinsip-prinsip musyawarah sangat menentang sikap hidup absolutisme dan monolitisme hal ini yang merupakan main idea dari demokrasi sesungguhnya. Kita tentunya ingat bahwa demokrasi sangat menentang absolutisme dan monilitisme tadi. Musyawarah menurut Cak Nur dimungkinkan untuk digunakan bagi mengatasi absolutisme dan monolitisme tersebut tadi. Dengan menggunakan musyawarah bagi mengambil sebuah keputusan politik maka keputusan tersebut akan mempunyai sifat naluriah mengikat kepada semua orang yang telibat dalam pengambilan keputusan tersebut dari pada keputusan diambil didasarkan hanya kepada suara terbanyak saja.

Keenam, Prinsip Permufakatan Yang Adil. Cak Nur menilai bahwa permufakatan yang adil merupakan hasil akhir dari musyawarah yang sehat dan jujur jadi hal ini dengan tegas menolak jenis-jenis manipulasi, kolusi, korupsi dan buruk lainnya dalam praktek demokrasi temporer. Cak Nur juga menambahkan bahwa permufakatan harus diambil dengan cara-cara yang baik, jika permufakatan diambil dengan rekayasa tidak sehat maka keputusan yang diambil akan berimplikasi negatif sehingga proses kebaikan-kebaikan demokrasi akan termarjinalkan.

Ketujuh, Prinsip Perlunya

Pendidikan Demokrasi. Dalam 
pandangan Cak Nur prinsip ini memegang peran yang sangat penting. Apalagi dalam konteks kebangsaan kita sekarang yang sedang aktif-aktifnya belajar demokrasi. Cak Nur juga menambahkan bahwa demokrasi juga merupakan proses trial and error proses coba salah dalam demokrasi merupakan hal yang sangat wajar apalagi jika suatu negara sedang berada dalam proses transisi demokrasi tersebut. Cak Nur juga menambahkan bahwa dalam konteks ini perlunya mengedepankan konsistensi dan kesabaran dalam menjalani demokratisasi. ${ }^{17}$

\section{FILSAFAT ISLAM}

Sebelum pembahasan mengarah kepada pokok inti permasalahan dalam Filsafat Pendidikan Islam terlebih dahulu akan dipaparkan problem mendasardari filsafat itu sendiri. Filsafat merupakan pengetahuan tentang cara berfikir sistematis; pengetahuan tentang kritik yang radikal, artinya sampai ke akarakarnya; sampai pada konsekuensinya yang terakhir. Radiks artinya akar yang juga disebut arche sebagai ciri khas berfikir filosofis. Perbedaan dengan pengetahuan adalah adanya asumsi sebagai titik tolak yang disebut sebagai keyakinan filsafati (philosophical belief). Radikal tidak hanya asumsi yang dibicarakan, tetapi digunakan.

\footnotetext{
${ }^{17}$ Arizka Warganegara, Demokrasi Ala Nurcholish Madjid, http://www.arizkawarganegara.com/2008/09/de mokrasi-ala-nurcholish-madjid.html dalam Google. com diakses pada 5 april 2017
}

Filsafat adalah pengetahuan tentang berfikir sistematis; pengetahuan tentang pemahaman universal terhadap semua persoalan; dan pengetahuan tentang kebenaran pemikiran yang tanpa batas dan masalah yang tidak pernah tuntas. ${ }^{18}$

Sebenarnya apa yang ada dalam cakupan filsafat tidak hanya aspek sejarah melainkan juga subtansinya, dan bagian inilah yang sebenarnya harus mendapat perhatian lebih. Bagian subtansi ini meliputi bahasan metafisika, estetika, etika dan terutama logika dan epistemologi. Dengan demikian, apa yang dimaksud filsafat, sesungguhnya, lebih merupakan bahasan tentang proses berpikir. Filsafat adalah "metodologi berpikir", yaitu berpikir kritis-analitis dan sistematis. Filsafat lebih mencerminkan "proses" berpikir dan bukan sekedar "produk" pemikiran. ${ }^{19}$

$\begin{array}{lrr}\text { Filsafat apabila } & \text { direlasikan } \\ \text { dengan } & \text { pendidikan } & \text { akan } \\ \text { memperbincangkan } & \text { sekitar }\end{array}$
permasalahan-permasalahan praksis, maka pendidikan harus dibahas dan dilandasi dengan filsafati. Dengan kompleksnya permasalahan pendidikan dan pentingnya pendidikan bagi kehidupan manusia, pandangan filosofis sangat diperlukan dalam pendidikan. Fungsi filsafat dalam pendidikan menurut Brubachr seperti

18 Atang Abdul Hakim dan Beni Ahmad Saebani, Filsafat Umum dari Metologi Sampai Theofilosofi (Bandung: Pustaka Setia, 2008), hlm16

19 M. Amin Abdullah, "Pengantar: Filsafat Islam Bukan Hanya Sejarah Pemikiran", dalam A Khudori Shaleh, Wacana Baru Filsafat Islam (Yogyakarta: Pustaka Pelajar 2012) hlm. vii. 
dikutip Noor Syam (1987) meliputi fungsi spekulatif, normatif, kritik, fungsi teori bagi pratik, dan fungsi integratif. Kesemua unsur fungsi itu merupakan satu kesatuan penting yang harus melandasi penyelanggaraan pendidikan. $^{20}$

Muzayyin Arifin memaknai filsafat pendidikan Islam pada hakikatnya adalah konsep berpikir tentang kependidikan yang bersumberkan atau berlandaskan ajaran-ajaran agama Islam tentang hakikat kemampuan manusia untuk dapat dibina dan dikembangkan serta dibimbing menjadi manusia Muslim yang seluruh pribadinya dijiwai oleh ajaran Islam. Definisi ini memberikan kesan bahwa filsafat pendidikan Islam sama dengan filsafat pada umumnya. Dalam arti bahwa filsafat pendidikan Islam mengkaji tentang berbagai masalah yang ada hubungannya dengan pendidikan, seperti manusia sebagai subyek dan obyek pendidikan, kurikulum, metode, lingkungan, guru, dan sebagainya. Bedanya dengan filsafat pendidikan pada umumnya adalah bahwa di dalam filsafat pendidikan Islam, semua masalah kependidikan tersebut selalu didasarkan pada ajaran Islam yang bersumberkan ajaran Al-Quran dan Hadist. Dengan kata lain, bahwa kata Islam yang mengiringi kata filsafat pendidikan itu menjadi sifat, yakni sifat dari filsafat pendidikan itu sendiri.

Selain itu, terdapat pula pengertian filsafat pendidikan Islam menurut Omar Muhammad al-Taomy

20 Musaheri, Pengantar Pendidikan.( Yogyakarta; IRCiSOD, 2007), hlm. 240.
al-Syaibani. Menurutnya bahwa filsafat pendidikan Islam tidak lain adalah pelaksanaan pandangan filsafat dari kaidah filsafat Islam dalam bidang pendidikan yang didasarkan pada ajaran Islam. Lebih lanjut ia mengatakan supaya filsafat pendidikan Islam itu dapat memperoleh faedah, tujuan-tujuan dan fungsi-fungsi yang diharapkan dan diidamkan, filsafat itu harus diambil dari berbagai sumber. ${ }^{21}$ Sumber-sumber tersebut diperhatikan dalam menciptakannya berbagai faktor, dengan syarat sumber-sumber dan faktor-faktor itu semua harus dikaitkan dengan sumber Islam. Apa yang terkandung di dalamnya berupa aqidah yang benar yang dapat diterima oleh akal yang waras dan fitrah yang suci. Sumber itu sesuai dengan jiwa yang bersih dari segala cacat dan cela. ${ }^{22}$

Muzayyin Arifin, menyatakan bahwa mempelajari filsafat pendidikan Islam berarti memasuki arena pemikiran yang mendasar, sistematik, logis, dan menyeluruh (universal) tentang pendidikan, yang tidak hanya dilatarbelakangi oleh pengetahuan agama Islam saja, melainkan menuntut kita untuk mempelajari ilmu-ilmu yang relevan. Pendapat ini memberi petunjuk bahwa ruang lingkup filsafat pendidikan Islam adalah masalahmasalah yang terdapat dalam kegiatan pendidikan, seperti masalah tujuan pendidikan, masalah guru, kurikulum, metode dan lingkungan. Bagaimanakah

${ }^{21}$ Abuddin Nata, Filsafat Pendidikan Islam (Jakarta: Gaya Media Pratama, 2005), hlm. 15

22 Omar Mohammad al-Taomy alSyaibani, Falsafah Pendidikan Islam (Jakarta: Bulan Bintang, 1979), hlm. 38. 
semua masalah tersebut disusun, tentu saja harus ada pemikiran yang melatarbelakanginya. Pemikiran yang melatarbelakanginya ini disebut pendidikan Islam. Karena itu dalam mengkaji filsafat pendidikan Islam seseorang akan diajak memahami konsep tujuan pendidikan, konsep guru yang baik, konsep kurikulum, dan seterusnya yang dilakukan secara medalam, sistematik, logik, radikal dan universal berdasarkan tuntunan ajaran Islam, khususnya berdasarkan AlQuran dan Al-Hadist.

Dalam hubungan dengan ruang lingkup filsafat pendidikan Islam, Muzayyin Arifin lebih lanjut mengatakan bahwa ruang lingkup pemikirannya bukanlah mengenai halhal yang bersifat teknis oprasional pendidikan, melainkan segala hal yang mendasari serta mewarnai corak sistem pemikiran yang disebut filsafat itu. Dengan demikian, secara umum ruang lingkup pembahasan filsafat pendidikan Islam ini adalah pemikiran yang serba mendalam, mendasar, sistematis, terpadu, logis, menyeluruh dan universal mengenai konsep-konsep yang dimulai dari perumusan tujuan pendidikan, kurikulum, guru, metode, lingkungan dan seterusnya. ${ }^{23}$

Menurut pengamatan Amin Abdullah (1996), bahwa studi Islam di Perguruan Tinggi Agama Islam (IAIN) menghadapi dilema antara studi keilmuan dan pendekatan keagamaan, yang berakibat pada tertindihnya misi keilmuan oleh misi keagamaan, dan

${ }^{23}$ Abuddin Nata, Filsafat Pendidikan Islam (Jakarta; Gaya Media Pratama, 2005), hlm.16 - 17. begitu pula sebaliknya. Studi keilmuan mengandaikan perlunya pendekatan kritis, analitis, empiris, historis. Sedangkan pendekatan keagamaan lebih menonjolkan sikap pemihakan, idealitas, bahkan seringkali diwarnai pembelaan yang bercorak apologis dan bersifat partikular.

Kajian filsafat pendidikan Islam (sebagai salah satu sub disiplin studi Islam) di IAIN/STAIN/UIN tidak mustahil mengalami nasib serupa. Dalam arti di satu pihak lebih berorientasi pada dunia pemikiran dan analisis kritis, sedangkan di pihak lain lebih menonjolkan pemihakan (commitment), idealistik-tidak membumi, apologis dan partikular subyektif. Atau mungkin timbul pihakpihak lainnya yang berusaha mempertemukan kedua kubu tersebut atau bermunculan kubu pemikiran lainnya, sehingga menjadi mutualcomplementation. $^{24}$

$\begin{array}{ccr}\text { Diskursus } & \text { pemikiran } & \text { filsafat } \\ \text { pendidikan } & \text { Islam } & \text { juga }\end{array}$ mempertimbangkan pandanganpandangan para filosof dan ulama Islam yang selama berabad-abad telah merenungkan makna pendidikan dari sudut persoalan-persoalan mendasar, seperti siapa manusia, apa hakikatnya, darimana dia berasal, dan ke mana akan kembali. Filsafat pendidikan Islam yang setia terhadap konsep manusia semacam itu akan berfungsi sebagai latar belakang bagi dibangunnya sistem pendidikan Islam.

${ }^{24}$ Muhaimin, Wacana Pengembangan Pendidikan Islam (Yogyakarta: Pustaka Pelajar, 2004), hlm. 12. 
Dengan demikian, filsafat pendidikan Islam diperlukan sebagai aplikasi filsafat dalam pendidikan. Pendidikan membutuhkan filsafat karena masalah-masalah pendidikan tidak hanya menyangkut pelaksanaan pendidikan yang dibatasi pengalaman akan tetapi menyangkut fakta-fakta yang lebih luas dan mendalam serta lebih kompleks yang tidak dibatasi pengalaman atau fakta-fakta pendidikan dan tidak memungkinkan dapat dijangkau oleh sains pendidikan. $^{25}$

\section{E. IMPLEMENTASI KONSEP DEMOKRASI NURCHOLISH MADJID DALAM FILSAFAT PENDIDIKAN ISLAM}

Berkaitan dengan pendidikan, terlebih dahulu disepakati bahwa pembahasan ini meliputi makna pendidikan demokrasi dalam perspektif pemikiran Nurcholish Madjid, tujuan pendidikan demokratis, kurikulum pendidikan demokratis, metode, pendidik-peserta didik, dan evaluasi yang didasarkan pada prinsip demokratis sesuai dengan perspektif pemikiran Nurcholish. Namun, semua kerangka pembahasan pendidikan tersebut dibahas dengan menggunakan alur berpikir kritis, rasional dan sistematis sesuai dengan karakteristik berpikir filosofis.

Pendidikan dalam prespektif demokrasi lebih dimaknai sebagai kebebasan peserta didik untuk mengungkapkan ekspresinya dan

25 Ahmad Ali Riyadi, Filsafat Pendidikan Islam (Yogyakarta: Teras, 2010), hlm. 6. pendapatnya. Peserta didik diberi ruang untuk berkarya dan berpendapat yang rasional dan dipertanggungjawabkan. Pendidik bukanlah sebagai aktor melainkan spectator yang berusaha untuk mengawasi setiap proses belajarmengajar. Sehingga, pendidik tidakmendominasi selama rangkaian proses kegiatan belajar-mengajar berlangsung. Namun, pendidik yang diibaratkan sebagai spectator, bukan hanya sekedar mangawasi, tetapi jugamembina peserta didik agar proses kegiatan belajar dapat berjalan secara efektif dan demokratis. Dengan demikian, pendidik tetaplah sebagai tauladan yang dapat memberi contoh dan menginspirasi bagi para peserta didiknya.

Pendidikan dan masyarakat memang tidak bisa dipisahkan.Bahkan, pendidikan perlu terintegrasi dengan masyarakat agar dapat merespon berbagai persoalan yang terjadi di sekitarnya.Oleh karenanya, pendidikan Islam dapat menawarkansuatu solusi alternatif dalam memperbaiki kualitas masyarakat ke depan, agar ke depannya masyarakat dapat berperan aktif dalam mewujudkan cita-cita demokrasi.Pendidikan Islam dapat menjadi salah satu wadah dalam mempersiapkan sebuah masyarakat yang demokratis, asalkan di dalam pendidikan sudah terdapat konsep pendidikan yang demokratis.Dengan demikian,diperlukan adanya prinsipprinsip demokrasi seperti kebebasan berpikir, beragama dan berkeyakinan, persamaan hukum, hak dan kewajiban, tegaknya hukum, keadilan dan persatuan dalam pendidikan Islam. 
Semua prinsip-prinsip tersebut harus terkandung dan terakomodasi dalam pendidikan Islam.

Pendidikan Islam bukan lagi sekedar mencetak peserta didik yang beriman dan bertaqwa, melainkan peserta didik yang berwawasan demokratis, selain dapatmenghargai keanekaragaman budayadan bangsanya.Pendidikandemokratis,

berarti harus membingkai keislaman, keindonesiaan dan kemoderenan menjadi satu landasan utuh dalam rangka menciptakan suatu tatantan masyarakat yang islami, nasionalis dan modernis. Pendidikan yang Islami berarti mencetak peserta didik yang beriman dan bertaqwa baik secara sosial maupun individual. Pendidikan yang nasionalis berarti menanamkan jiwa nasionalis dalam peserta didik agar menghargai bangsanya, sekaligus dapat menghargai adanya kebhinekaan dalam rangka mempererat tali persatuan dan kesatuan bangsa.Pendidikan yang modernis berarti mencetak peserta didik yang berwawasan demokratis, memiliki pengetahuan luas, serta dapat mengembangkan ilmu pengetahuan dan teknologi dengan tujuan menjunjung tinggi harkat dan martabat kemanusiaan universal.

Pendidikan harus membuka ruang selebar-lebarnya bagi peserta didik untuk beraktivitas, berinovasi dan berkreasi.Beraktivitas berarti, peserta didik perlu belajar mandiri, mengaktifkan diskusi, ikut serta dalam kegiatan sosial, aktif dalam berorganisasi dan seterusnya.Berinovasi berarti peserta didik perlu menumbuhkan semangat untuk berani melakukan eksperimen, sehingga menghasilkan penenmuanpenemuan baru yang dapat bermanfaat bagi masyarakat dan lingkungan.Selain itu, rancang-bangun matapelajaran di dalamnya harus mengandungunsur nilai-nilai demokratis, supaya mencetak peserta didik yang memiliki wawasan terbuka dan egaliter. Dalam kegiatan belajar-mengajar perlu ditumbuhkembangkan adanya minat dan potensi peserta didik agar ke depan mereka dapat dengan mudah dalam menumbuhkan kreasi dan inovasi.

Peserta didik perlu ditanamkan nilai-nilai yang memprioritaskan harkat dan martabat kemanusiaan universal.Nilai-nilai yang dapat membawa peserta didik untuk menghargai keragaman di Nusantara. Perbedaan perlu dihargai, namun tetap meyakini adanya persamaan di balik keanekaragaman yang ada.Pada hakikatnya manusia itu memiliki perberdaan, namun dibalik perbedaan terdapat persamaan.Dari sinilah, diperlukan konsep "kalimatun sawa" untuk menemukan titik temu diantara perbedaan-perbedaan yang dijumpai.Peserta didik perlu disadarkan bahwa paham kesamaan manusia bukan berarti menafikan adanya keunikan dan perbedaan di dalamnya, melainkan harus bersikap adil dan objektif.Selain mengakui adanya persamaan, juga perlu disadari bahwa perbedaan adalah keunikan yang diberikan Tuhan kepada manusia. Sehingga, proses penyelenggaraan demokrasi akan berjalan sesuai dengan 
harapan apabila manusia saling menghargai antara satu dengan lainnya.

Metode belajar yang tepat dalam demokratisasi pendidikan ialah "diskusi" kelompok. Di sini, peserta didik diberi kebebasan berpikir dan berpendapat, keberanian untuk menyampaikan ide-ide dan pemikirannya, serta ada ruang bebas bagi mereka untuk saling berdialog dan berdialektika. Dengan dibukanya ruang dialog, maka peserta didik dapat berpikir kritis dan menelaah lebih lanjut informasi-informasi yang mereka dapatkan. Dengan sistem dialog akanmenumbuhkan semangat musyawarah yang menjadi ruh dalam demokrasi. Peserta didik bukan hanya diberi kesempatan untuk menyampaikan pendapatnya, tetapi juga harus memberi kesempatan kepada orang lain yang berbeda pendapat untuk mengekspresikan gagasannya. Selain itu, mereka harus dibimbing oleh pendidik supaya tumbuh sikap kedewasaan dalam rangka menerima perbedaan-perbedaan yang mungkin muncul ketika berlangsungnya dialog.

Tujuan pendidikan berbasis demokrasi dalam perspektif pemikiran Nurcholish Madjid ialah terciptanya kebersamaan, perubahan, dan perkembangan melalui pendidikan. Kebersamaan yang dimaksud ialah perlunya mengupayakan untuk membuka kesempatan bagi peserta didik agar dapat berpartisipasi secara bersama-sama dalam proses kegiatan belajarnya, berpartisipasi untuk mengungkapkan ekspresi dan pendapatnya tanpa saling mendominasi, karena semua peserta didik memiliki hak yang sama dalam pendidikan. Tidak ada kesan superior dari pendidik kepada peserta didik.

Peserta didik harus memiliki pandangan objektif bahwa setiap orang adalah cerdas dan pandai, berbakat, berprestasi dan meraih penghargaan sesuai dengan potensi, kemampuan dan usaha yang mereka jalankan. Dengan demikian, tidak ada rasa superior atau inferior, tinggi dan rendah, bodoh dan pintar, yang mengarah pada rasa egois, sombong, atau rendah diri dalam proses belajar dan mengajar. Bahkan, peserta didik dapat bekerjasama dengan peserta didik lain, berdialog, berdiskusi, dan saling menimba informasi dan wawasan pengetahuan. Darisinilah maka akantumbuh sikap keterbukaan peserta didik dalam memandang fenomena yang dijumpainya dengan sangat beragam.

Sebagai salah satu komponen dalam menciptakan perubahan, maka pendidikan Islam harus terus mengupayakan adanya perubahanperubahan ke arah yang lebih positif untuk menciptakan suatu tatanan yang ideal dalam kehidupan masyarakat.Perubahan-perubahan

tersebut perlu dilakukan untuk terciptanya suatu tatanan yang baru dan demokratis. Perubahan itu diawali dengan perubahan karakter peserta didik menjadi peserta didik yang berkarakter kuat-positif.Dengan perubahan itu, maka peserta didik dapat membina dan menjalin hubungan yang harmonis di dalam suatu masyarakat.Perubahan juga terjadi pada pengetahuan yang bersifat 
revolusioner. Pengetahuan tidak lagi mempertahankan doktrin-doktrin yang ada, tetapi juga diperlukan adanya wawasan dan pengetahuan yang baru agar peserta didik tidak terasing dengan ruang dan waktu. Mereka lebih siap untuk menghadapi globalisasi dan modernisasi, menguasai teknologi yang berkembang, dan memiliki wawasan pengetahuan yang luas.

Pendidikan Islam perlu berupaya mengembangkan sistem pendidikannya ke arah yang lebih progresif. Sistem pendidikan Islam yang demokratis di dalamnya harus memuat nilai-nilai yang demokratis. Pengembangan dapat dimulai dengan mengembangkan kurikulum yang semula masih memuat nilai-nilai yang dogmatis-doktriner, kemudian dikembangkan lagi dengan memadukan antara nilai-nilai normatifdoktriner denganhistoris-empiris. Memadukan matapelajaran yang di dalamnya masih kuat unsur dogmatisdoktrinernya, dengan matapelajaran yang kuat unsur historis-empirisnya. Jadi, seperti halnya slogan yang selalu didengung-dengungkan oleh Nurcholish yakni keislaman, keindonesiaan, dan kemoderenan. Maka, dalam kurikulum pendidikan Islam perlu dipadukan antara matapelajaran yang bersifat normatifdoktriner (ilmu-ilmu keagamaan Islam) dengan matapelajaran umum yang bersifat historis-empirik (modernitas) sekaligus ditambah dengan nilai-nilai nasionalis dan pancasilais (keindonesiaan).

Dalam perspektif Nurcholish, pendidikan Islam yang demokratis perlu merespon gejala-gejala sosial yang terjadi dalam masyarakat. Persoalan-persoalan yang umumnya dihadapi oleh masyarakat seperti diskriminasi, ketimpangan ekonomi, ketidakadilan sosial, konflik sosial, konflik antar suku, agama dan ras, perlu mendapat respon pendidikan Islam. Sebagai agen perubahan sosial, maka pendidikan Islam harus memberikan solusi, agar persoalanpersoalan tersebut dapat diminimalisasi. Di sinilah, diperlukan konsep untuk merancang pendidikan Islam yang sensitif terhadap persoalan yang ada dalam masyarakat. Konsep tersebut diawali dengan perubahan kurikulum di dalamnya. Perlunya ditanamkan sikap kepedulian sosial terhadap peserta didik dan ditanamkannya semangat kebangsaan dan nilai-nilai kultur (budaya lokal), yang ada di tempat sekitar. Pendidikan Islam adalah pendidikan yang membawa nilai-nilai Islami sekaligus pendidikan yang peduli dengan kebudayaan setempat yang tidak bertentangan dengan nilai-nilai Islam.

Dalam evaluasi, maka sudah seharusnya diterapkan prinsip objektif dengan memandang dan menilai peserta didik sesuai dengan fakta dan realita mereka. Di sinilah peran pendidik untuk mengevaluasi lebih lanjut kekurangan-kekurangan, problem-problem, dan hal-hal apa saja yang perlu dievaluasi dari peserta didik untuk lebih diperbaiki lagi ke depan. Oleh karenanya, proses evaluasi harus menjujung tinggi prinsip demokratis, adil dan objektif.

Dalam pendidikan demokrasi, berarti harus memberikan ruang seluas- 
luasnya kepada peserta didik untuk mengembangkan kompetensi yang dimilikinya. Pendidik harus memahami realitas objektif peserta didik dalam bidang kompetensi yang mereka miliki. Karena manusia adalah makhluk dengan segala individualitasnya. Artinya masing-masing peserta didik memiliki cirikhas tersendiri berdasar potensi yang dimiliki, sehingga peserta didik adalah sebagai subyek bukan lagi hanya sebagai objek. ${ }^{26}$

Pendidik perlu menyadari bahwa setiap peserta didik memiliki kompetensi, baik kompetensi dalam bidang matematika, ilmu alam, sosial, seni, olahraga, pidato, bahasa dan seterusnya. Pendidik harus memberikan kesempatan seluas-luasnya kepada peserta didik untuk mengembangkan potensinya. Dengan demikian, tidak ada rasa superior dan inferior dalam memandang peserta didik, karena pendidik memandang peserta didik secara demokratis.

\section{F. KESIMPULAN}

Ada beberapa poin yang dapat disimpulkan dalam filsafat pendidikan Islam yang demokratis sesuai dengan perspektif pemikiran Nurcholish Madjid. Poin tersebut ialah. Pertama, pendidikan Islam demokratis berarti pendidikan Islam yang memprioritaskan asas kebersamaan, perubahan dan perkembangan. Kedua., pendidikan Islam perlu menanamkan nilai-nilai keindonesiaan dan kemoderenan.

${ }^{26}$ Ngainun Naim dan Achmad Sauqi, Pendidikan Multikultural...., hlm. 61.
Pendidikan Islam perlu berupaya untuk membuka kesempatan bagi peserta didiknya untuk dapat berpartisipasi secara bersama-sama dalam proses kegiatan belajarnya, berpartisipasi untuk mengungkapkan ekspresi dan pendapatnya tanpa saling mendominasi, karena semua peserta didik memiliki hak yang sama dalam pendidikan. Pendidikan Islam harus terus mengupayakan adanya perubahan-perubahan ke arah yang lebih positif untuk menciptakan suatu tatanan yang ideal dalam kehidupan masyarakat. Perubahan-perubahan tersebut perlu dilakukan untuk terciptanya suatu tatanan yang baru dan demokratis. Pendidikan Islam juga turut serta berupaya mengembangkan sistem pendidikannya ke arah yang lebih progresif. Sistem pendidikan Islam yang demokratis di dalamnya harus terhadap muatan-muatan nilainilai demokratis.

Pendidikan Islam harus membingkai keislaman, keindonesiaan dan kemoderenan menjadi satu landasan yang utuh dalam rangka menciptakan suatu tatantan masyarakat yang islami, nasionalis dan modernis.Pendidikan yang Islami berarti mencetak peserta didik yang beriman dan bertaqwa baik secara sosial maupun individual. Pendidikan yang nasionalis berarti mencetak peserta didik yang memiliki jiwa nasionalis terhadap bangsanya, sekaligus dapat menghargai adanya kebhinekaan dan mempererat tali persatuan dan kesatuan bangsa. Pendidikan yang modernis berarti mencetak peserta didik yang 
berwawasan

demokratis,

mengembangkan ilmu pengetahuan dan teknologi, sebagai upaya untuk menjunjung tinggi harkat dan martabat kemanusiaan universal.

\section{DAFTAR PUSTAKA}

Abdullah, M. Amin, "Pengantar: Filsafat Islam Bukan Hanya Sejarah Pemikiran", dalam A Khudori Shaleh, Wacana Baru Filsafat Islam. Yogyakarta: Pustaka Pelajar 2012

Al-Syawy,Taufiq, Syura Bukan Demokrasi, terj. Jamaluddin ZS. Jakarta: Gema Insani Pers, 1992. Al-Syaibani, Omar Mohammad alTaomy,Falsafah Pendidikan Islam. Jakarta: Bulan Bintang, 1979.

Apter,Dafid E. Pengantar Analisa Politik, terj. Tim Yogosama. Jakarta: Rajawali, 1989.

Bakker, Anton \& Ahmad Charis Zubair, Metodologi Penelitian Filsafat. Yogyakarta: Kanisius, 1990.

Hakim, Atang Abdul dan Beni Ahmad

Saebani, Filsafat Umum dari Metologi Sampai Theofilosofi. Bandung: Pustaka Setia, 2008. Imarah,Muhammad,Perang

Terminologi Islam Versus Barat. Jakarta: Rabbani Press, 1998.

Madjid, Nurcholish,Pintu-pintu Menuju Tuhan. Jakarta: Dian Rakyat, 2008.

dan Peradaban. Jakarta: Dian Rakyat. 2008.
Muhaimin, Wacana Pengembangan Pendidikan Islam. Yogyakarta: Pustaka Pelajar, 2004.

Musaheri, Pengantar Pendidikan.Yogyakarta; IRCiSOD, 2007.

Na'im, Ngainun dan Achmad Sauqi, Pendidikan Multikultural: Konsep dan Aplikasi.Yogyakarta: Ar-Ruzz Media, 2010.

Nasution, Khoiruddin, Pengantar Studi Islam. Yogyakarta: Accademia, 2009.

Nata,Abuddin,Filsafat Pendidikan Islam (Jakarta: Gaya Media Pratama, 2005

Nurkhalis, Konstruksi Demokrasi dalam Pemikiran Nurcholish Madjid dalam "Sosio-Religia Vol. 10, No.1, Februari 2012”.

Shofan, Moh,Pluralisme

Menyelamatkan AgamaAgama.Yogyakarta: Samudra Biru, 2011.

Singh, Bilver dan Abdul Munir Mulkhan, Jejaring Radikalisme Islam di Indonesia: Jejak Sang Pengantin Bom Bunuh Diri. Yogyakarta: JogjaBangkit Publisher, 2012.

Suharto, Toto,Filsafat Pendidikan Islam. Yogyakarta: Ar-Ruzz, 2006.

Riyadi,Ahmad Ali,Filsafat Pendidikan Islam. Yogyakarta: Teras, 2010.

Umiarso dan Zamroni, Pendidikan Pembebasan dalam Perspektf Barat dan Timur.Yogyakarta; ArRuzz Media, 2011.

The New Encyclopedia Britannica, Vol. 4, Micropaedia, 
Encyclopedia Britania Inc,. Ney York: Chicago Press, 1988.

Online :Pengertian Demokrasi, Macam-macam, ciri-ciri, definisi para ahli, prinsip dan nilai http://www.artikelsiana.com/201 5/08/demokrasi-pengertian-ciriciri-macam.html

David Edison, Konsep Nurcholish Madjid Tentang Demokrasi Indonesia, http://www.kompasiana.com/051 01988/konsep-nurcholishmadjid-tentang-demokrasiindonesia_550efbb5813311c82cb c66b2 dalam Google.com diakses pada 4 April 2017

Arizka Warganegara, Demokrasi Ala Nurcholish Madjid, http://www.arizkawarganegara.co $\mathrm{m} / 2008 / 09 /$ demokrasi-alanurcholish-madjid.html dalam Google. com diakses pada 5 april 2017 